\title{
HUBUNGAN ANTARA DIMENSI BIG FIVE PERSONALITY DENGAN RIWAYAT KECELAKAAN SOPIR DI PERUSAHAAN " $X "$
}

\author{
Indiana Yanuar, Noeroel Widajati \\ Departemen Kesehatan dan Keselamatan Kerja, \\ Fakultas Kesehatan Masyarakat, Universitas Airlangga, Surabaya. \\ Email: indiyanuar@gmail.com
}

\begin{abstract}
Data Global Status Report on Road Safety released by WHO in 2012 showed as many as 1.24 million people worldwide died from traffic accidents. According to the Police Data Korlantas 2011-2013, Trucks ranks third as a vehicle that frequent accidents. Based on these conditions, do research on the truck driver in the company " $X$ " Pasuruan. This study aims to determine the relationship between working time, rest time and the type of personality through the big five personality theory with a history of occupational accidents suffered by truckers in the company " $X$ ". This was an analytical study with a cross-sectional approach. The subject of this study was the truck driver as many as 70 people taken by simple random sampling technique. This research was conducted in the town of Pasuruan in 2016. The data were analyzed by univariate and bivariate analysis. Results of this research, between working time and rest time with a history of occupational accidents were no relationship. Meanwhile there were relationship between the type of Conscientiousness in the big five personality with a history of occupational accidents according to statistics chi-square test with sig 0.036. The driver who had a history of workplace accidents is dominated by a driver with that type has a characteristic is not intended or too much pursuit of the goal, lazy, inattentive, reckless, undisciplined, and likes to have fun. It can be considered companies in the recruitment process.
\end{abstract}

Keywords: truck driver, big five personality, occupational accidents

\begin{abstract}
Abstrak: Data Global Status Report on Road Safety yang dikeluarkan WHO tahun 2012 menunjukkan sebanyak 1,24 juta orang di seluruh dunia meninggal karena kecelakaan lalu lintas. Menurut Data Korlantas Polri 2011-2013, Truk menempati peringkat ketiga sebagai kendaraan yang sering mengalami kecelakaan. Berdasarkan kondisi tersebut maka dilakukan penelitian pada sopir truk di Perusahaan "X" Pasuruan. Penelitian ini bertujuan untuk mengetahui hubungan antara waktu kerja, waktu istirahat dan dimensi kepribadian melalui teori big five personality dengan riwayat kecelakaan yang dialami sopir truk di Perusahaan "X". Desain penelitian termasuk penelitian analitik dengan pendekatan cross-sectional. Subjek dari penelitian ini adalah sopir truk sebanyak 70 orang yang diambil dengan teknik simple random sampling. Penelitian ini dilakukan di kota pasuruan pada tahun 2016. Data akan dianalisis menggunakan analisis univariat dan bivariat. Hasil menunjukkan jika tidak ada hubungan antara waktu kerja dan waktu istirahat dengan riwayat kecelakaan yang pernah dialami sopir. Sementara itu terdapat hubungan antara dimensi Conscientiousness dalam big five personality dengan riwayat kecelakaan menurut uji statistik chi-square dengan nilai sig 0,036 . Sopir yang memiliki riwayat kecelakaan didominasi oleh sopir dengan dimensi tersebut memiliki cirri-ciri tidak bertujuan atau terlalu banyak mengejar tujuan, malas, kurang perhatian, sembrono, tidak disiplin, dan suka bersenang-senang Hal ini dapat menjadi bahan pertimbangan perusahaan dalam proses rekrutmen.
\end{abstract}

Kata kunci: sopir truk, big five personality, kecelakaan.

\section{PENDAHULUAN}

Jumlah kecelakaan di Indonesia terus meningkat setiap tahunnya. Data Korlantas Polri 2011-2013 menyatakan bahwa tingkat kecelakaan sebesar 34,48\% terjadi pada pagi hari dan 24,14\% pada sore hari. Berdasarkan jenis kendaraan yang mengalami kecelakaan adalah sepeda motor sebesar 52,5\%, mobil pribadi $20 \%$, truk $17,5 \%$ dan bus $10 \%$. Truk menempati peringkat ketiga sebagai kendaraan yang sering mengalami kecelakaan.

Menurut data di Perusahaan "X" pada tahun 2015 telah terjadi 16 kecelakaan di 
jalan yang melibatkan truk dari perusahaan " $X$ " di seluruh Indonesia. Jumlah tersebut setara dengan jumlah kecelakaan truk yang terjadi di area pabrik perusahaan " $X$ " Pasuruan pada tahun 2015 yaitu, sekitar 17 kecelakaan.

Dampak dari kecelakaan yang dialami sopir truk tersebut dapat menjadi masalah terhadap kelangsungan sebuah perusahaan. Kerugian yang diderita perusahaan tidak hanya berupa materi saja namun, perusahaan juga akan mengalami gangguan pada proses produksi karena hilangnya waktu kerja dari tenaga kerja yang mengalami kecelakaan, sehingga nantinya akan memengaruhi produktivitas perusahaan.

Penyebab kecelakaan yang dialami sopir pada umumnya terdiri atas 4 (empat) faktor yaitu faktor manusia, faktor kendaraan, faktor jalan dan faktor lingkungan. Faktor manusia diantaranya seperti kesehatan sopir, pengetahuan sopir, perilaku sopir dan dimensi kepribadian sopir.

Faktor kendaraan terdiri dari cacat produksi, tahun kendaraan dan fungsi kendaraan yang tidak optimal. Faktor Jalan diantaranya jalan yang berlubang, desain jalan, penerangan jalan dan rambu-rambu jalan. Faktor lingkungan terdiri dari cuaca dan bencana (Corona Indonesia Club, 2010).

Faktor manusia memang sering kali diungkapkan sebagai faktor yang paling dominan. Menurut Teori Heinrich dan teori Swiss cheese model dari Reason, unsafe act atau perilaku tidak aman merupakan penyebab langsung dari kecelakaan.

Unsafe act adalah sebuah perilaku tidak aman yang dilakukan seseorang. Perilaku tersebut dapat terjadi dipengaruhi oleh banyak faktor, salah satunya faktor kepribadian. Salah satu teori yang membahas tentang hubungan antara kepribadian dan kecelakaan adalah The accident proneness theory. Menurut teori ini, beberapa orang mempunyai karakteristik permanen yang memungkinkan orang tersebut mengalami kecelakaan. Hinze menyebutkan, bahwa Vernon pada tahun 1918 telah menyatakan kecenderungan kecelakaan bisa diusut ke ciri kepribadian (Hinze, 1997).

Sebuah penelitian tentang dimensi kepribadian dan kecelakaan di sektor transportasi telah dilakukan oleh Fine (1963). Hasil dari penelitian tersebut, pengemudi yang extrovert memiliki catatan kecelakaan lebih banyak dibanding dimensi kepribadian lainnya. Penelitian serupa yang dilakukan di Indonesia oleh Fikri pada tahun 2015, menunjukkan adanya hubungan yang signifikan antara dimensi kepribadian dengan kecelakaan lalu lintas yang dialami sopir di provinsi Riau.

Beberapa hasil penelitian yang sudah dilakukan tersebut menunjukkan adanya kecenderungan pada hubungan antara dimensi kepribadian dengan kejadian kecelakaan. Extravert yang telah dibahas dalam penelitian sebelumnya merupakan salah satu dimensi dalam Big five personality selain empat dimensi lainnya, Agreeableness, Conscientiousness Neuroticism, dan Openness.

Berdasarkan teori dan penelitian yang sudah dilakukan sebelumnya, maka perlu dilakukan penelitian lebih lanjut tentang dimensi kepribadian pekerja berdasar teori big five personality apakah memiliki hubungan yang signifikan dengan riwayat kecelakaan yang dialami sopir truk.

Tujuan dari penelitian ini adalah untuk Menganalisis hubungan antara dimensi big five personality dengan riwayat kecelakaan pada sopir Truk di perusahaan " $X$ " Pasuruan.

\section{METODE}

Penelitian ini jika ditinjau dari tempat penelitian maka, penelitian ini termasuk dalam penelitian observasional atau lapangan. Desain penelitian ini berupa studi cross-sectional.

Populasi dari penelitian ini adalah seluruh sopir truk yang terdaftar sebagai sopir truk di Perusahaan "X" Pasuruan yang berjumlah 193 orang.

Sampel yang diambil menggunakan simple random sampling dengan jumlah sampel 70 orang yang mewakili populasi 193 sopir truk pengangkutan barang dengan menggunakan rumus sampel dari Nursalam (2008).

Penelitian ini di lakukan di Perusahaan "X" yang terletak di kabupaten Pasuruan Provinsi Jawa Timur pada bulan November 
2016. Variabel independen dari penelitian ini adalah riwayat kecelakaan, sedangkan variabel dependen dari penelitian ini adalah dimensi kepribadian berdasarkan teori big five personality.

Teknik pengumpulan data dalam penelitian ini menggunakan data primer melalui kuesioner dan data sekunder dari perusahaan dan instansi terkait. Peneliti akan memberikan dua macam kuesioner. Kuesioner riwayat kecelakaan akan ditanyakan dengan metode wawancara, sedangkan kuesioner dimensi kepribadian akan diisi sendiri oleh responden yang bersangkutan.

Kuesioner merupakan instrumen dalam penelitian ini. Kuesioner dimensi kepribadian merupakan alat ukur dimensi kepribadian menggunakan Big Five Inventory untuk mengetahui dominasi dari dimensi dalam big five personality. Kuesioner ini terdiri dari 44 pernyataan dengan skala likert yang mewakili 5 dimensi dari big five personality. Dimensi Extraversion memiliki 8 pertanyaan, dimensi Agreeableness memiliki 9 pertanyaan, dimensi Conscientiousness memiliki 9 pertanyaan, dimensi Neuroticism memiliki 8 pertanyaan dan dimensi Openness memiliki 10 pertanyaan. Total nilai dari setiap dimensi akan dikategorikan menjadi dua kategori, yaitu kategori rendah dan tinggi dengan menggunakan nilai median, diantaranya, kategori rendah untuk nilai kurang dari nilai median dan kategori tinggi untuk nilai lebih tinggi atau sama dengan median.

Instrumen lain dalam penelitian ini adalah kuesioner riwayat kecelakaan. Alat ukur riwayat kecelakaan ini menggunakan kuesioner yang berisi pertanyaan tentang kecelakaan yang pernah dialami selama menjadi sopir truk.

Data dianalisis menggunakan analisis univariat dan bivariat. Analisis bivariat digunakan untuk mengetahui adanya hubungan antara variabel independen dan variabel dependen dengan menggunakan Uji Chi Square.

\section{HASIL PENELITIAN}

Perusahaan " $X$ " memiliki 3 area produksi yang terbagi menjadi 5 line produksi. Setiap line produksi memiliki mesin produksi yang akan menghasilkan produk dengan jumlah yang berbeda-beda. Produk yang dihasilkan dari kelima Line tersebut akan didistribusikan ke konsumen dengan menggunakan sarana transportasi berupa truk. Truk pengangkutan galon tersebut dikemudikan oleh 193 sopir dengan berbagai jenis kendaraan dan tersebar ke berbagai rute perjalanan.

Kegiatan yang terkait dengan sopir diantaranya adalah proses pengangkutan produk. Proses ini dilakukan berdasarkan customer order atau CO. Setiap CO memiliki window atau jam operasional yang dapat digunakan untuk pengambilan barang. Perusahaan "X" membagi waktu operasional pengambilan barang menjadi 6 window. Setiap window memiliki batas waktu 4 jam dalam proses pengambilan barang. Jika truk datang sebelum atau melebihi waktu dari window yang tertera di CO maka, truk tersebut tidak dapat melakukan pengambilan barang dan harus mengganti dengan $\mathrm{CO}$ yang baru.

Alur pengangkutan produk dimulai dari lembar CO. Lembar CO yang dibawa oleh sopir truk akan diserahkan pada ruang $\mathrm{COC}$ untuk dilakukan entry data, lalu sopir akan mendapatkan nomer antrean. Sopir akan masuk ke area pabrik saat nomer antrean telah dipanggil. Sebelum nomor antrean dipanggil, sopir menyiapkan truk yang dibawanya lalu akan dilakukan pemeriksaan truk oleh security menggunakan lembar check list kendaraan. Security melakukan pengecekan kondisi ban utama, kebocoran rem, rem tangan, dan ID card sopir. Setelah truk lolos verifikasi yang dilakukan security maka truk baru diperbolehkan masuk.

Beberapa jenis truk dengan bak terbuka mengharuskan sopir untuk membuka terpal terlebih dahulu sebelum masuk ke area pabrik dan menutup terpal kembali setelah selesai melakukan pengambilan barang. Setelah tahap verifikasi selesai dilakukan dan nomor antrean telah dipanggil, sopir akan masuk ke area pabrik dan melakukan bongkar galon kosong atau unloading terlebih dahulu. Setelah selesai proses bongkar maka truk akan melakukan proses loading galon isi. 
Pada saat proses loading dilakukan sopir memiliki waktu sekitar 30 menit untuk istirahat. Setelah proses loading berakhir, sopir akan mengambil surat jalan dan kelengkapan lainnya sebelum keluar dari area pabrik. Pada saat menunggu surat jalan dan kelengkapan lain, biasanya para sopir melakukan proses tutup terpal untuk truk dengan bak terbuka. Proses tutup terpal tidak dilakukan oleh sopir sendiri, sering kali sopir menggunakan jasa kernet atau pun kernet tembakan. Kernet tembakan merupakan warga sekitar yang dipekerjakan menjadi kernet selama proses uploading dan loading di area pabrik.

Penerapan safety di area transportation menggunakan beberapa program safety yang ditujukan untuk sopir. Program tersebut diantaranya, memberikan rambu-rambu, petugas traffic police, safety cone, safety full body harness (digunakan saat proses buka dan tutup terpal), Check list truk, serta program safety briefing untuk sopir.

Check list truk merupakan tahapan yang wajib dilakukan sebelum kendaraan masuk ke area pabrik. Check list dibagi menjadi dua macam, yang pertama adalah check list rutin yang dilakukan setiap truk akan masuk ke area pabrik, lalu yang kedua adalah check list keseluruhan, dilakukan setiap satu bulan sekali oleh bagian COC.

Setelah lolos pengecekan keseluruhan truk akan memperoleh sticker lolos verifikasi yang ditempel di kendaraan. Pada sticker lolos verifikasi terdapat tanggal masa berlaku selama satu bulan dari tanggal pengecekan. Jika tanggal masa berlaku telah habis maka harus dilakukan pengecekan ulang.

Setiap kendaraan yang akan masuk ke lokasi pabrik harus melalui pemeriksaan yang dilakukan oleh pihak COC. Lembar check list terdiri dari dua bagian yang dicek, kelengkapan utama dan kelengkapan umum.

Kelengkapan utama terdiri dari kondisi ban, kebocoran rem, rem tangan, keikutsertaan Defensive Driver Training (DDT) yang dibuktikan dengan kepemilikan ID CARD, SIM, STNK, KEUR, seat belt, alarm mundur dan lampu-lampu kendaraan, ganjal ban, dan Tali pengikat atau tensioner. Sementara untuk kelengkapan umum

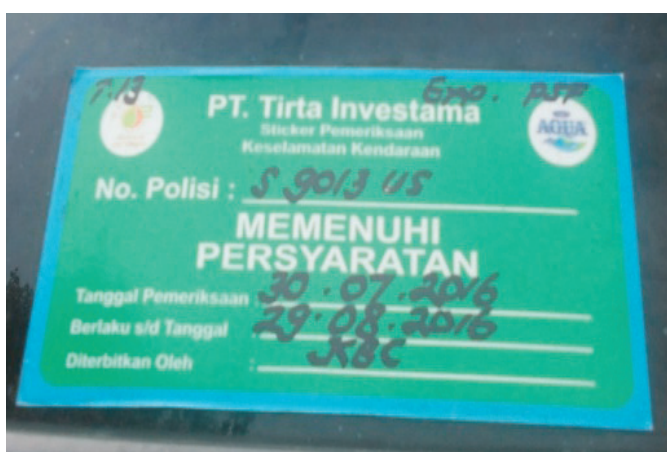

Gambar 1. Sticker Truk.

diantaranya, apakah ada kebocoran pada mesin, kaca spion, klakson, api, APAR, Kotak P3K, segitiga pengaman, kondisi kondisi ban dan bak, serta kondisi wipper.

Selain check list, program safety lainnya yang diterapkan di area transportation adalah safety briefing yang dilakukan secara rutin setiap rabu sore dan jumat pagi di area ruang tunggu sopir. Materi yang dibahas dalam briefing ini diantaranya mencakup permasalahan safety dan quality di area pabrik yang berhubungan dengan sopir truk. Peserta dari briefing ini adalah sopir, kernet, perwakilan dari tenaga bongkar muat, perwakilan dari gudang, safety dan quality serta perwakilan dari security.

Safety Briefing ini dilakukan dengan metode briefing dan tanya jawab di akhir sesi. Sesi Tanya jawab juga merupakan salah satu media sharing yang disediakan bagi para sopir, untuk bisa bertanya serta memberikan saran dan kritik demi perbaikan yang berkaitan dengan safety transportation. Program ini dilakukan di ruang tunggu sopir, selain itu tersedia juga kopi yang merupakan salah satu daya tarik bagi para sopir untuk dapat bergabung dalam program ini. Program ini diharapkan mampu mengurangi angka kecelakaan pada sopir truk.

Safety briefing dilakukan dengan cukup santai agar hubungan antara pembicara dan peserta bisa mencair, sehingga peserta dapat mendengarkan materi yang disampaikan dengan baik, serta dapat memberi feedback berupa saran dan kritik pada pihak perusahaan. Safety Briefing nantinya diharapkan mampu meningkatkan pengetahuan serta safety behaviour dari sopir truk, sehingga dapat mengurangi jumlah kecelakaan yang terjadi. 


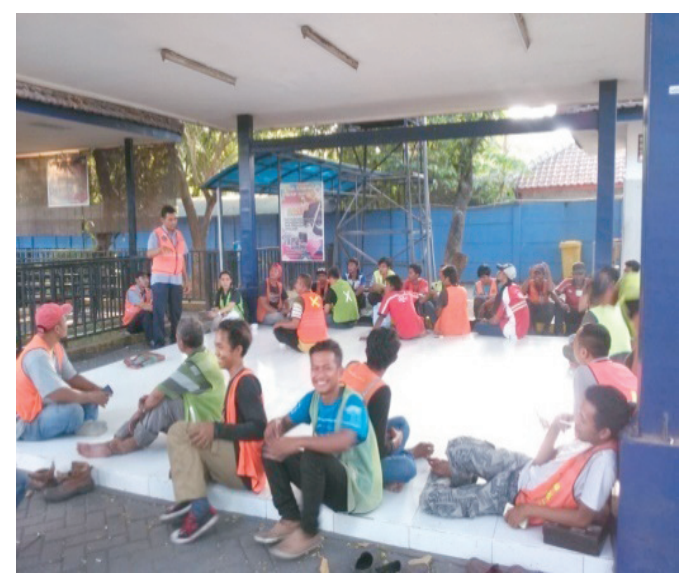

Gambar 2. Safety briefing.

Selama program ini dijalankan, telah terjadi beberapa perubahan dari perilaku sopir dan kernet. Sopir dan kernet terlihat lebih antusias mengikuti program Safety Briefing dan lebih mematuhi aturan dalam pemakaian alat pelindung diri. Salah satunya pemakaian safety full body harness, sebelumnya sopir dan kernet enggan menggunakan APD saat menutup atau membuka terpal, namun sekarang sopir dan kernet selalu memakai APD. Ketika APD yang disediakan kurang sesuai atau rusak justru sopir dan kernet yang akan melaporkan dan meminta APD yang lebih sesuai.

Gambaran umum karakteristik sopir truk pada tabel 1 menunjukkan Distribusi frekuensi usia sopir truk dari 70 responden, sebagian besar responden ada pada kategori usia antara 36-45 tahun, didominasi dengan sopir truk berpendidikan SMA, memiliki masa kerja antara kurang dari 5 tahun dan lebih dari 5 tahun dan sebagian dari sopir belum mengikuti DDT namun sudah memiliki ID CARD.

Berdasarkan Tabel 2 menunjukkan dimensi yang memiliki skor tinggi adalah dimensi Extraversion, Agreeableness, Conscientiousness dan Openness. Sementara untuk dimensi Neuroticism, sebagian besar responden memiliki nilai yang rendah. Pekerja dengan skor tinggi pada dimensi extraversion menunjukkan bahwa pekerja memiliki kecenderungan bersifat ramah, tegas, penuh semangat, antusias, dominan, dan komunikatif, mereka berinteraksi
Tabel 1. Distribusi Frekuensi Karakteristik Sopir Truk

\begin{tabular}{lrr}
\hline Karakteristik Responden & Frekuensi & \% \\
\hline Kategori Usia & 3 & 4.5 \\
$17-25$ & 19 & 27 \\
$26-35$ & 29 & 41.5 \\
$36-45$ & 12 & 17 \\
$46-55$ & 7 & 10 \\
\hline $56-65$ & $\mathbf{7 0}$ & $\mathbf{1 0 0}$ \\
\hline Total & & \\
\hline Tingkat Pendidikan & 1 & 1.4 \\
S1 & 26 & 37.2 \\
SMA & 19 & 27.1 \\
SMP & 3 & 4.3 \\
Tidak Sekolah & 21 & 30 \\
SD & $\mathbf{7 0}$ & $\mathbf{1 0 0}$ \\
\hline Total & & \\
\hline Masa Kerja & 37 & 53 \\
$<5$ & 33 & 47 \\
\hline 5 & $\mathbf{7 0}$ & $\mathbf{1 0 0}$ \\
\hline Total & & \\
\hline Keikutsertaan DDT & 35 & 50 \\
YA & 35 & $50 \mathrm{~s}$ \\
TIDAK & $\mathbf{7 0}$ & $\mathbf{1 0 0}$ \\
\hline Total & & \\
\hline
\end{tabular}

dengan lebih banyak orang. Sementara skor tinggi pada Agreeableness menunjukkan seseorang memiliki kecenderungan tunduk kepada orang lain, berhati lembut, baik, suka menolong, dapat dipercaya dan mudah memaafkan serta dimanfaatkan.

Berbeda halnya dengan dimensi Conscientiousness, skor tinggi pada dimensi ini dicirikan sebagai seorang dengan nilai kebersihan dan ambisi yang tinggi, seseorang yang well organize, tepat waktu, teratur, dapat dipercaya, pekerja keras, disiplin, teliti, rapi, ambisius dan tekun.

Dimensi terakhir yang memiliki skor tinggi adalah Openness, skor tinggi menunjukkan mereka memiliki ciri mudah bertoleransi, memiliki kapasitas untuk menyerap informasi, menjadi seseorang yang sangat fokus dan mampu untuk waspada pada perasaan, memiliki pikiran yang imfulsivitas.

Sementara untuk dimensi Neuroticism, sebagian besar responden memiliki skor rendah, hal tersebut menunjukkan mereka adalah seseorang yang lebih mudah merasa puas, gembira dan emosi positif lain dalam kehidupannya. Sifat-sifat tersebut 
Tabel 2. Tabel Hasil Penelitian Big Five Personality.

\begin{tabular}{lcc}
\hline $\begin{array}{c}\text { Dimensi Big Five } \\
\text { Personality }\end{array}$ & Frekuensi & \% \\
\hline Extraversion & & \\
$\quad$ Rendah & 32 & 45,7 \\
$\quad$ Tinggi & 38 & 54,3 \\
\hline Total & $\mathbf{7 0}$ & $\mathbf{1 0 0}$ \\
\hline Agreeableness & & \\
$\quad$ Rendah & 21 & 30 \\
$\quad$ Tinggi & 49 & 70 \\
\hline Total & $\mathbf{7 0}$ & $\mathbf{1 0 0}$ \\
\hline Conscientiousness & & \\
$\quad$ Rendah & 30 & 42,9 \\
$\quad$ Tinggi & 40 & 57,1 \\
\hline Total & $\mathbf{7 0}$ & $\mathbf{1 0 0}$ \\
\hline Neuroticism & & \\
$\quad$ Rendah & 37 & 52,9 \\
$\quad$ Tinggi & 33 & 47,1 \\
\hline Total & $\mathbf{7 0}$ & $\mathbf{1 0 0}$ \\
\hline Openness & & \\
Rendah & 28 & 40 \\
$\quad$ Tinggi & 42 & 60 \\
\hline Total & $\mathbf{7 0}$ & $\mathbf{1 0 0}$ \\
\hline
\end{tabular}

Tabel 3. Distribusi Frekuensi Riwayat kecelakaan yang dialami Sopir Truk.

\begin{tabular}{lcr}
\hline Riwayat kecelakaan & Frekuensi & $\mathbf{\%}$ \\
\hline Tidak Pernah & 52 & 74.3 \\
Pernah & 18 & 25.7 \\
\hline Total & $\mathbf{7 0}$ & $\mathbf{1 0 0 . 0}$ \\
\hline
\end{tabular}

berkebalikan dari responden dengan skor rendah.

Tabel 3 menunjukkan data kecelakaan yang pernah dialami sopir truk, diketahui dari 70 responden, sebagian besar sopir tidak pernah mengalami kecelakaan selama bekerja, hanya sekitar 18 orang saja yang pernah mengalami kecelakaan.

Kecelakaan yang paling banyak dialami sopir truk berupa property damage dan tidak menyebabkan korban jiwa. Berdasarkan riwayat kecelakaan yang dialami sopir tersebut, diketahui 11 kecelakaan berdampak pada kerusakan properti, sedangkan 6 diantaranya adalah kecelakaan yang menyebabkan korban luka dan 1 diantaranya menyebabkan korban jiwa.

Hubungan antara dimensi dalam big five personality dan riwayat kecelakaan digambarkan pada tabel 4. Berdasarkan tabel 4, diketahui Extraversion, Agreeableness, Neuroticism dan Openness tidak memiliki hubungan dengan riwayat kecelakaan karena $\mathrm{p}$ value $>\alpha$ atau Ho diterima.

Berdasarkan tabel 4 diketahui, sopir dengan skor rendah pada dimensi Conscientiousness justru lebih banyak yang mengalami kecelakaan dibandingkan dengan skor tinggi pada dimensi ini.

Analisis data pada tabel 4 menggunakan uji chi square tersebut menunjukkan bahwa nilai $\mathrm{p}$ value sebesar 0,036 dengan derajat kemaknaan $\alpha=0,05$, sehingga

Tabel 4. Crosstabulation Waktu Kerja dan Riwayat Kecelakaan.

\begin{tabular}{|c|c|c|c|c|c|}
\hline \multirow{2}{*}{$\begin{array}{c}\text { Dimensi Big Five } \\
\text { Personality }\end{array}$} & \multirow{2}{*}{ Skor } & \multicolumn{2}{|c|}{ Riwayat Kecelakaan } & \multirow{2}{*}{ Total } & \multirow{2}{*}{ P Value } \\
\hline & & Pernah & Tidak Pernah & & \\
\hline \multirow{3}{*}{ Extraversion } & Rendah & 8 & 24 & 32 & \multirow{2}{*}{1,00} \\
\hline & Tinggi & 10 & 28 & 38 & \\
\hline & Total & 18 & 52 & 70 & \multirow{3}{*}{0,59} \\
\hline \multirow{3}{*}{ Agreeableness } & Rendah & 4 & 17 & 21 & \\
\hline & Tinggi & 14 & 35 & 49 & \\
\hline & Total & 18 & 52 & 70 & \multirow{3}{*}{0,036} \\
\hline \multirow{3}{*}{ Concientiousness } & Rendah & 12 & 18 & 30 & \\
\hline & Tinggi & 6 & 34 & 40 & \\
\hline & Total & 18 & 52 & 70 & \multirow{3}{*}{0,27} \\
\hline \multirow{3}{*}{ Neuroticism } & Rendah & 7 & 30 & 37 & \\
\hline & Tinggi & 11 & 22 & 33 & \\
\hline & Total & 18 & 52 & 70 & \multirow{4}{*}{0,065} \\
\hline \multirow{3}{*}{ Openness } & Rendah & 11 & 17 & 28 & \\
\hline & Tinggi & 7 & 35 & 42 & \\
\hline & Total & 18 & 52 & 70 & \\
\hline
\end{tabular}


$\mathrm{p}$ value $<\alpha$ atau Ho ditolak sehingga menunjukkan adanya hubungan antara dimensi Conscientiousness dengan riwayat kecelakaan sopir truk.

\section{PEMBAHASAN}

Pengecekan yang dilakukan telah sesuai dengan Undang-undang Republik Indonesia Nomor 22 tahun 2009 tentang Lalu Lintas dan Angkutan Jalan pasal 49. Pada pasal tersebut dijelaskan pengujian berkala meliputi pemeriksaan dan pengujian fisik kendaraan bermotor dan pengesahan hasil uji.

Check list yang dilakukan di Perusahaan " $X$ " telah sesuai dengan cara pengecekan yang tertera di pasal 54 dalam Undang-undang Republik Indonesia Nomor 22 tahun 2009 tentang Lalu Lintas dan Angkutan Jalan. Bukti lulus uji berkala hasil pemeriksaan dan pengujian fisik akan mendapatkan kartu uji dan tanda uji.

Kartu uji berkala memuat keterangan tentang identifikasi Kendaraan Bermotor dan identitas pemilik, spesifikasi teknis, hasil uji, dan masa berlaku hasil uji. Tanda uji berkala sebagaimana dimaksud pada ayat memuat keterangan tentang identifikasi Kendaraan Bermotor dan masa berlaku hasil uji. Sementara dalam perusahaan "X" bukti lulus uji berkala tidak berupa kartu tapi berupa sticker yang ditempel di kaca kendaraan. Jadi perusahaan " $X$ " telah membuat kebijakan sesuai dengan peraturan perundangan yang berlaku.

Menurut hasil penelitian tentang karakteristik individu responden, diketahui sopir truk paling banyak berada pada usia produktif dan menjelang masuk ke kelompok usia tidak produktif. Kondisi tersebut menunjukkan jika sopir truk yang menjelang masuk pada kelompok usia tidak produktif masih dapat bekerja dengan baik sama dengan kelompok usia produktif. Hal tersebut menunjukkan jika beban kerja yang dialami sopir truk pada perusahaan " $X$ " masih bisa dijalankan oleh kelompok usia lebih dari 40 tahun, namun bisa saja akan mengalami penurunan seiring bertambahnya usia. Kondisi tersebut seperti yang diungkapkan Wisnu Sentana (2013). Penelitiannya menyatakan bahwa, usia berpengaruh secara positif terhadap produktivitas seorang pekerja.

Berbeda halnya dengan usia, jika dilihat berdasarkan pendidikan formal yang telah ditempuh, Sopir truk lebih banyak berada pada tingkat pendidikan SMA dan sedikit yang pada tingkat pendidikan SD atau bahkan tidak sekolah. Jadi sebagian besar atau hampir keseluruhan sopir telah menempuh pendidikan formal.

Berdasarkan penelitian yang dilakukan oleh Martha Monroza Siagian pada tahun 2010, terdapat pengaruh antara pendidikan dan pelatihan yang telah diterima pegawai dinas tenaga kerja kota Medan terhadap kinerjanya. Hal tersebut sejalan dengan hasil penelitian ini, pendidikan pada sopir juga dapat mendukung kinerja sopir selama bekerja. Tingkat pendidikan sopir menunjukkan sebagian besar sopir truk bisa membaca dan menulis sehingga tidak akan kesulitan dalam membaca rambu-rambu lalu lintas yang ada di jalan. Kondisi tersebut akan mendukung Sopir dalam bekerja sehingga dapat terhindar dari kecelakaan.

Seperti halnya usia dan tingkat pendidikan, jumlah yang tidak terlalu berbeda jauh juga ditemukan pada masa kerja sopir truk. Lamanya kerja dapat memengaruhi kinerja seseorang baik positif maupun negatif seperti halnya yang diungkapkan Tulus (1992). Masa kerja memberi pengaruh positif pada kinerja bila dengan semakin lamanya masa kerja seseorang akan menjadi semakin berpengalaman dalam melaksanakan tugasnya. Semakin berpengalaman dapat membuat pekerja lebih berhati-hati dan bisa terhindar dari kecelakaan. Sebaliknya akan memberikan pengaruh negatif apabila dengan semakin lamanya masa kerja dengan pengalaman yang sudah banyak, justru akan membuat pekerja meremehkan dan tidak mengindahkan bahaya sehingga dapat memicu terjadinya kecelakaan.

Sementara dalam hal keikutsertaan DDT justru terdapat kesamaan jumlah antara sopir yang pernah mengikuti training DDT dengan sopir yang belum mengikuti training. Kondisi tersebut menunjukkan jika syarat keikutsertaan DDT sebelum mendapatkan ID card pada sopir tidak sepenuhnya dipenuhi oleh distributor. Hal 
ini lah yang perlu menjadi perhatian bagi pihak perusahaan karena tidak semua sopir truk yang bekerja telah memenuhi syarat yang telah dibuat perusahaan.

Syarat pemberian training DDT sendiri dibuat perusahaan untuk para sopir truk yang akan bekerja di perusahaan. Syarat tersebut diberikan pada Distributor agar pihak distributor melakukan training DDT sebelum memberikan ID card pada sopir. Training ini bertujuan untuk meningkatkan pengetahuan sopir truk sehingga nantinya diharapkan mampu mengurangi kecelakaan pada sopir truk.

Menurut Sugandi (2003), Kecelakaan merupakan suatu kejadian atau peristiwa yang tidak diinginkan dan bersifat merugikan terhadap manusia, merupakan harta benda atau kerugian proses. Sedangkan menurut Word Health Organization (WHO) mendefinisikan kecelakaan sebagai suatu kejadian yang tidak dapat dipersiapkan penanggulangan sebelumnya, sehingga menghasilkan cidera yang riil. Sopir truk di perusahaan " $X$ " yang pernah mengalami kecelakaan ketika mengemudi truk lebih sedikit dibandingkan sopir truk yang tidak pernah mengalami kecelakaan. Sebagian besar kecelakaan yang dialami sopir tersebut merupakan property damage dan tidak memakan korban jiwa.

Kecelakaan yang sering dialami sopir truk di dalam area pabrik juga lebih banyak berupa property damage. Beberapa kasus kecelakaan tersebut, berawal dari sopir yang sering kali tidak mengindahkan komando dari traffic police sehingga truk pun akan salah arah sampai akhirnya menabrak.

Selain itu beberapa kasus kecelakaan juga terjadi karena kurang kooperatifnya Tenaga Kerja Bongkar Muat (TKBM) dalam mematuhi aturan safety, sehingga sering membuat sopir pun akhirnya menjadi ikut tidak mematuhi aturan safety. Sopir sering dihadapkan pada posisi sulit karena harus bergantung dari bantuan TKBM dalam proses bongkar dan muat, jadi sopir akan menuruti permintaan TKBM sekalipun hal tersebut menyalahi aturan safety yang berlaku.

Beberapa pelanggaran yang dilakukan sopir dan terjadi karena TKBM adalah tidak digunakannya papan peluncur saat bongkar barang, sehingga barang akan rawan terjatuh ke berbagai arah tanpa bisa diprediksi. Hal tersebut dapat menyebabkan barang terjatuh dan menimpa pekerja yang ada di sekitar area bongkar.

Kendala yang dialami perusahaan saat ini adalah sulitnya untuk mengatur para TKBM yang berasal dari warga sekitar pabrik. TKBM berpengaruh besar pada kecelakaan yang terjadi dan pada perilaku sopir selama di area pabrik. Sopir cenderung menuruti apa yang dilakukan TKBM agar proses bongkar muat berjalan lancar. Hal tersebut lah yang dapat memicu terjadinya kecelakaan karena perilaku TKBM masih kurang safety dan jarang menggunakan alat pelindung diri. TKBM hanya bekerja dengan cepat tanpa memedulikan keselamatan dan kesehatannya.

Gambaran dimensi Kepribadian Sopir Truk Dengan Teori Big Five Personality, berdasarkan screening pada 5 dimensi yang dimiliki responden menurut teori Big Fie Personality, responden sebagian besar memiliki nilai yang tinggi untuk dimensi Extraversion, Agreeableness, Conscientiousness, dan Openness. Sementara untuk dimensi Neuroticism sebagian besar responden memiliki nilai yang rendah.

Nilai yang tinggi pada dimensi Conscientiousness cukup sesuai dengan pekerjaan sopir, mereka digambarkan sebagai seorang dengan nilai kebersihan dan ambisi yang tinggi, seseorang yang well organize, dan tepat waktu (McRae, 1992). Hal tersebut sesuai dengan aturan pengambilan berdasar window yang telah ditetapkan perusahaan, sebagian besar sopir dapat mematuhi dan melaksanakan aturan tersebut dengan baik. Jadi aturan pengambilan barang yang telah ditetapkan perusahaan tersebut sesuai dengan dimensi Conscientiousness.

Selain dimensi Conscientiousness dimensi lain yang juga cukup sesuai dengan pekerjaan sopir adalah dimensi Agreeableness. Dimensi ini menilai kecenderungan seseorang yang tunduk kepada orang lain, mereka orang yang komparatif dan mudah bersepakat serta mempercayai orang lain. Berdasar kondisi tersebut maka, sopir truk memiliki 
kecenderungan untuk mematuhi aturan yang ada, sehingga perusahaan dapat membuat SOP serta peraturan yang sesuai untuk mengurangi kecelakaan.

Selain melalui SOP, perusahaan juga dapat menambah atau lebih menguatkan peran traffic police. Berdasar dimensi Agreeableness, peran traffic police akan dapat memengaruhi mereka, namun terdapat kekurangan sifat mudah bersepakat dan mempercayai orang lain. Ketergantungan sopir pada kinerja dari TKBM justru dapat membuat sopir mudah bersepakat dengan TKBM sekalipun hal tersebut tidak mematuhi traffic police. Sopir akan cenderung lebih bersepakat pada TKBM agar proses bongkar dan muat dapat dilaksanakan dengan baik. Jadi berdasarkan kondisi tersebut maka, perusahaan juga harus mengatur para TKBM agar dapat bekerja sesuai dengan SOP dan aturan yang berlaku di perusahaan.

Sebaliknya menurut McRae (1992), untuk nilai tinggi pada dimensi openness dapat membuat sopir lebih kreatif dan berpikir imfulsivitas atau lebih menekankan pada dorongan perasaan. Kondisi perasaan sopir yang buruk dapat memengaruhi konsentrasi sopir ketika mengemudi.

Lapisan terakhir dari teori Swiss Cheese Model, James T. Reason (1990) yang dapat berdampak langsung dalam terjadinya kecelakaan adalah unsafe action. Unsafe action yang dilakukan sopir seperti melanggar rambu-rambu lalu lintas merupakan perilaku tidak aman yang dipengaruhi oleh tingkat pendidikan sopir, masa kerja sopir dan dimensi kepribadian sopir.

Teori tersebut mendukung hasil uji statistik yang menunjukkan adanya hubungan antara dimensi Conscientiousness dalam Big five Personality dengan riwayat kecelakaan yang dialami sopir truk di perusahaan "X". Sejalan dengan hasil uji statistik tersebut, Penelitian yang dilakukan Wulandari tahun 2014 juga menyatakan bahwa terdapat hubungan antara kepribadian dan kecelakaan dengan nilai $\mathrm{p}$ sebesar 0,016 .

Selain itu menurut Fikri, dkk (2015) menyatakan bahwa terdapat pengaruh yang signifikan antara kepribadian dengan kecelakaan lalu lintas yang terjadi pada sopir bus di Provinsi Riau. Hal tersebut berdasarkan penelitian yang dilakukan pada sopir bus jarak jauh di provinsi Riau dengan menggunakan Big Five Personality Inventory dan angket kecelakaan lalu lintas.

Berdasarkan tabel 5.8 sebagian besar sopir truk yang mengalami kecelakaan adalah sopir yang memiliki nilai rendah dalam dimensi Conscientiousness. Orang dengan nilai rendah pada dimensi tersebut cenderung tidak bertujuan atau bahkan terlalu banyak mengejar tujuan, malas, kurang perhatian, lalai, sembrono, tidak disiplin, keinginan lemah, dan suka bersenang-senang. (Pervin dkk, 2010).

Ciri-ciri yang dimiliki sopir dengan nilai rendah pada dimensi ini, seperti lalai, sembrono, tidak disiplin sangat memungkinkan sopir untuk bertindak tidak aman atau unsafe action. Sehingga diperlukan program safety yang sesuai agar cirri-ciri tersebut tidak memengaruhi kinerja sopir.

Berdasarkan kondisi tersebut, perusahaan "X" dapat melakukan pencegahan kecelakaan berdasar sifatsifat yang dimiliki dimensi tersebut. Salah satunya dengan cara meningkatkan pengetahuan melalui kegiatan safety briefing yang selama ini telah dilakukan dan refresh DDT secara rutin dengan materi yang selalu di update.

Pengetahuan yang baik diharapkan mampu mendorong sopir untuk bertindak aman ketika bekerja. Selain itu dapat pula dengan membuat aturan atau SOP secara terperinci sehingga sopir dapat melaksanakan aturan tersebut dengan baik. Selain itu perlu juga penambahan jumlah traffic police yang sesuai dengan kondisi di area pabrik, sehingga terdapat pengawasan dari traffic police pada para sopir saat menjalankan kendaraan di area pabrik dan aturan yang telah ditetapkan pun dapat dipatuhi dengan baik sesuai dengan rincian yang telah dibuat.

\section{KESIMPULAN}

Perusahaan "X" Pasuruan yang memiliki 5 line produksi yang terdiri dari 5 mesin yang berbeda dan memiliki 193 
personel sopir untuk mendistribusikan barangnya. Karakteristik sopir pada perusahaan " $X$ " seluruhnya berjenis kelamin laki-laki, dan berada pada usia produktif dengan tingkat pendidikan paling banyak SMA, serta didominasi sopir dengan masa kerja kurang dari 5 tahun.

Berdasarkan teori Big Five Personality, dimensi yang memiliki skor tinggi adalah dimensi Extraversion, Agreeableness, Conscientiousness dan Openness. Sementara untuk dimensi Neuroticism, sebagian besar responden memiliki nilai yang rendah.

Hasil screening terhadap kepribadian berdasar teori big five personality tersebut menunjukkan sifat-sifat dasar yang dimiliki sopir berdasarkan 5 dimensi Big Five Personality. Sifat-sifat dasar tersebut dapat menjadi pedoman bagi perusahaan untuk melakukan program pencegahan kecelakaan serta pembuatan kebijakan yang terkait sopir, agar program dan kebijakan yang dibuat dapat sesuai dan dilaksanakan dengan baik.

Menurut analisis data menggunakan $u j i$ chi square, diketahui bahwa ada hubungan antara dimensi Conscientiousness dengan riwayat kecelakaan yang dialami sopir. Responden dengan skor rendah pada dimensi Conscientiousness lebih banyak mengalami kecelakaan dibanding dengan responden dengan skor tinggi.

Responden dengan skor rendah diketahui memiliki sifat sembrono, malas, tidak disiplin dan sering kali lalai. Sifat-sifat tersebut dapat menjadi pemicu terjadinya unsafe action. Berdasarkan kondisi tersebut maka perlu dilakukan pencegahan agar sifatsifat dominan tersebut dapat dikurangi atau dicegah agar tidak menjadi unsafe action.

\section{SARAN}

Saat melakukan rekrutmen sopir truk, sebaiknya dilakukan pula pengukuran dimensi kepribadian untuk mengetahui sopir truk memiliki kecenderungan bersikap seperti apa, sehingga dapat menjadi salah satu bahan pertimbangan guna mencegah terjadinya kecelakaan.

Program safety yang terkait safety transportation semakin ditingkatkan dengan menambah program lain agar lebih bervariatif. Berdasar hasil penelitian perlu membuat program pencegahan kecelakaan yang terkait safety transportation berdasarkan hasil screening big five personality. Pencegahan yang dapat dilakukan dengan membuat peraturan serta SOP tentang bongkar muat barang yang dibuat secara terperinci dengan menggunakan media flow chart. Setelah itu dapat dilakukan sosialisasi pada sopir truk dan pekerja lainnya.

Berdasar hasil penelitian ini, tipe Conscientiousness memiliki hubungan dengan riwayat kecelakaan kerja pada sopir, maka pencegahan yang dapat dilakukan dengan menambah jumlah traffic police yang sesuai, sehingga pengawasan dapat dilakukan secara optimal. Selain itu dengan menerapkan sistem reward dan punishment untuk para sopir.

Pemberian materi DDT atau refresh tentang DDT pada sopir truk dan seluruh sopir yang ada di perusahaan sebaiknya dilakukan secara rutin sebagai bentuk antisipasi apabila pihak Distributor belum memberikan training DDT pada Sopir Truk. Selain sopir, training DDT juga dapat dilakukan pada para pekerja di bagian gudang serta area transportation.

Pemberian peraturan bagi para TKBM agar dapat bekerja dengan aman dan menggunakan alat pelindung diri. Selain peraturan yang diterapkan, perlu juga dilakukan pula sosialisasi dan pemberian penyuluhan atau materi tentang safety transportation pada para TKBM.

Mengembangkan program safety briefing yang sudah ada dengan mencatat setiap hasil briefing ke dalam sebuah agenda, sehingga masalah atau masukan yang dibahas akan selalu tercatat dan terkontrol, sehingga tidak ada yang terlewatkan. Selain itu perlu dilakukan pengkajian ulang terhadap catatan briefing di agenda tersebut secara rutin, jadi problem yang belum terselesaikan bisa terpantau.

\section{DAFTAR PUSTAKA}

Adolf, Heuken S. J. 1979. Pedoman untuk Mengenal Diri, Tantangan Membina Kepribadian, Jilid I \& II cet. ke 3. Yogyakarta: Kanisius. 
Bouwer, Herman. 1978. Ground Water Hidrology New York : McGraw-Hill Book Company.

BPS. 2014. Data Statistik Transportasi Darat. Jakarta: CV. Ryan Indah.

Budiono. 2003, Bunga Rampai Hiperkes dan KK, Semarang, Badan Penerbit Universitas Diponegoro Semarang.

Ghani, Mohammad, A. 2003. Sumber Daya Manusia Perkebunan Dalam Perspektif. Jakarta: Ghalia.

Goldberg, Lewis, R. 1992. "The Development of Makers for the Big-Five Factor Structure." Psychological Assessment, Vol. 7, No. 1: 26-42.

Heinrich, H.W. 1931. Industrial accident prevention. New York: McGraw-Hill Book Company.

Hinze, Jimmie, W. 1997. Construction Safety. New Jersey: Prentice Hall Inc.

Idris, F., Napitupulu., L. 2015. Pengaruh Faktor Kepribadian, Stres Kerja Terhadap Kecelakaan Jalan Raya Pada Supir Bus di Provinsi Riau. Jurnal Universitas Islam Riau, Vol 09 (No. 03): pp 1-12. Tersedia di:<http://jurnal.uir.ac.id/index.php/ JAN/ article/view/404/342> [Diakses tanggal 15 April 2016].

ILO. 1962. Encylopedia of Occupational Health and Safety. Geneva: ILO.

Kartika, Metta. 2009, Analisis Faktor Penyebab Kecelakaan Lalu Lintas Pada Pengendara Sepeda Motor di Wilayah Depok (Menggunakan Data Kecelakaan Polres Metro Depok Tahun 2008), Skripsi, Universitas Indonesia.

McCrae, R.R., \& Costa, P. T. 1992. NEO PI-R Professional Manual, Psychological Assess, Florida: Odessa.

Notoatmodjo, Soekidjo. 2005. Metodologi Penelitian Kesehatan. Jakarta: Penerbit Rineka Cipta.

Nursalam. 2008. Konsep dan Penerapan Metodologi Penelitian Keperawatan. Jakarta.
O'Keeffe, T. and D. Harrington. 2001. Learning to Learn: an Examination of Organizational Learning in Selected Irish Multinationals, Journal of European Industrial Training, Vol.25, No.2/3/4.

Pervin, Laurence dkk. 2010. Psikologi Kepribadian Teori dan Penelitian, Jakarta: Kencana.

Reason, James, T. 1990. Human Error. Cambridge: Cambridge University Press.

Republik Indonesia. 1993. Peraturan Pemerintah Nomor 43 Tahun 1993 tentang Prasarana Jalan Raya dan Lalu Lintas.

Republik Indonesia. 2009. Undang-undang Nomor 22 Tahun 2009 tentang Lalu Lintas dan Angkutan Jalan.

Robbins, Stephen, P. 2006. Perilaku Organisasi. Jakarta: Prehallindo.

Siagian, Martha, M. 2010. Pengaruh Pendidikan dan Pelatihan terhadap Kinerja Pegawai Dinas Tenaga Kerja Kota Medan. Skripsi, Universitas Hasanuddin.

Sugandi, Acmad dan Haryanto. 2003. Teori Pembelajaran. Semarang: IKIP.

Suma'mur Pk, Dr, Msc. 1998. Hygiene Perusahaan dan Kesehatan. Jakarta: CV Haji Mas Agung, cetakan ke 6.

Tarwaka. 2008. Manajemen dan Implementasi K3 di Tempat Kerja, Surakarta: Harapan Press.

Tulus, Agus. 1992. Manajemen Sumber Daya Manusia, Jakarta: PT. Gramedia Pustakatama.

Underwood, Geoffrey. 2005. Traffic and Transport Psychology Theory and Application. Amsterdam: Elsevier B.V.

WHO. 2013. Global status Report on Road Safety, Geneva: Department of Violence and Injury Prevention and Disability (VIP).

Wibisono, Darmawan. 2006. Manajemen Kinerja. Jakarta: Penerbit Erlangga.

Yinger, J. Milton. 1982. Counterculture: The Promise and Peril of a World Turned Upside Down New York; The Free Press. 